Kocaeli Üniversitesi Sağlık Bilimleri Dergisi

\title{
EMPATHIC TENDENCIES AND EMPATHIC SKILL LEVELS OF NURSING STUDENTS: A DESCRIPTIVE AND CROSS-SECTIONAL STUDY
}

\author{
HEMŞIRELIK ÖĞRENCILERINIIN EMPATIK E ĞILIMLERİ VE EMPATIK BECERİ DÜZEYLERİ: \\ TANIMLAYICI VE KESITSEL ÇALIŞMA
}

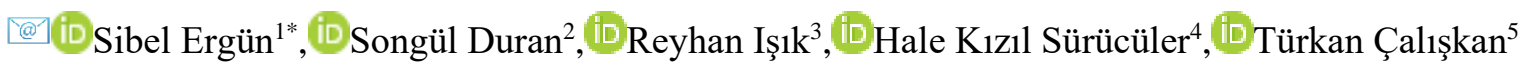

1Balıkesir University, Faculty of Health Sciences, Department of Nursing, Balıkesir, Turkey
2Demokrasi University, Vocational School of Health Services Elderly Care Program, İzmir, Turkey
${ }^{3}$ Balıkesir University, School of Health Sciences, Balıkesir, Turkey
${ }^{4}$ Balıkesir University, School of Health Sciences, Balıkesir, Turkey
${ }^{5}$ Balikesir University, Faculty of Health Sciences, Department of Nursing, Balıkesir, Turkey

ORCID iD: Sibel Ergün: 0000-0003-1227-5856; Songül Duran: 0000-0002-2565-7784; Reyhan Isık: 0000-0002-0664-2261; Hale K1z1l Sürücüler: 0000-0002-1541-0884; Türkan Çalışkan: 0000-0002-7808-2363

*Corresponding Author / Sorumlu Yazar: Sibel Ergün, e-mail / e-posta: sibel.ergun@balikesir.edu.tr

\begin{abstract}
Objective: This descriptive and cross-sectional study was conducted to determine empathic tendencies and empathic skill levels of nursing students. Methods: The population of this study consisted of 580 nursing students. Interviews were conducted with 412 students. The data were collected using a Personal Information Form, the Empathic Tendency Scale and the Empathic Skill Scale (ESS). Evaluation of the data was performed with calculation, t-test and analysis of variance (ANOVA).

Results: Among the students, $64.8 \%(\mathrm{n}=267)$ were within the 20-22 age group, $87.6 \%(\mathrm{n}=361)$ were female, and $27.2 \%(\mathrm{n}=112)$ were enrolled in the fourth year. The mean of the Empathic Tendency Scale was $68.84 \pm 8.42$, and the mean score on the ESS was $139.67 \pm 20.11$. Empathic Tendency Scale and Empathic Skill Scale scores were statistically significant according to gender, age and class year $(p<0.05)$. The mean scores of the female students on the Empathic Tendency Scale and Empathic Skill Scale were the highest for those in the 23-25 age groups and in the fourth year.

Conclusions: The result concluded that mean scores on the Empathic Tendency Scale and Empathic Skill Scale of nursing students were at a medium level. It is important to support students during their professional education.
\end{abstract}

Keywords: Empathy, nursing, students

Öz

Amaç: Tanımlayıcı ve kesitsel olan bu çalışma, hemşirelik öğrencilerinin empatik eğilim ve empatik beceri düzeylerinin belirlenmesi amacıyla yapılmıştır.

Yöntem: Bu çalışmanın evrenini 580 hemşirelik öğrencisi oluşturmuş, 412 öğrenciye ulaşılmıştır. Veriler kişisel bilgi formu, Empatik Eğilim Ölçeği ve Empatik Beceri Ölçeği aracılığıyla toplanmıştır. Bulguların değerlendirilmesinde yüzdelik, t testi ve varyans analizi (ANOVA) kullanılmıştır.

Bulgular: Araştırma kapsamına alınan öğrencilerin \%64,8'i (n=267) 20-22 yaş grubunda, \%87,6's1 (n=361) k1z öğrencidir. Öğrencilerin \%27,2'si

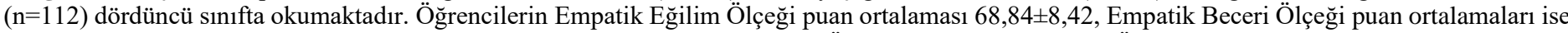
$139,67 \pm 20,11$ 'dir. Cinsiyetlerine, yaşlarına ve sınıfına göre Empatik Eğilim Ölçeği ve Empatik Beceri Ölçeği puanları istatistiksel olarak anlamlı düzeyde farklılık göstermektedir $(p<0,05)$. Empatik eğilim ve Empatik beceri puan ortalamaları kızlarda, $23-25$ yaş grubunda ve dördüncü sınıflarda yüksek olduğu bulunmuştur.

Sonuç: Çalışma sonunda hemşirelik öğrencilerinin empatik eğilim ve empatik beceri puan ortalamaları orta düzeyde saptanmış olup, öğrencilerin bu konuda mesleki eğitimleri sırasında desteklenmeleri gerektiği düşünülmüştür.

Anahtar Kelimeler: Empati, hemşirelik, ögrenci 


\section{Introduction}

Empathy is the ability to sense other people's emotions and to understand their internal state, including their thoughts and feelings. ${ }^{1,2}$ Barret-Lennard described empathy as a cyclical process characterized by three phases: empathic resonation, empathic communication, and the resulting received/ perceived empathy. ${ }^{3}$ Dökmen addressed two dimensions of empathy, namely, empathic tendency (ET) and empathic skill (ES). Empathic tendency is the emotional component of empathy and demonstrates the potential of an individual to show empathy in daily life. Empathic skill, on the other hand, refers to an individual's ability to empathize. ${ }^{4}$ In this regard, empathy is considered an important communication skill in furthering people's understanding of each other. ${ }^{5}$ Orlando's theory calls attention to the reciprocal relationship between patient and nurse, wherein individualism plays a significant role. This theory suggests that the development of communication and empathy among patients and nurses is very important for determining the physical, emotional and social requirements of patients. ${ }^{6}$ An empathic approach is fundamental to the therapeutic relationship between nurse and patient. ${ }^{7}$ Patients express themselves in a more comfortable way when empathy skills are applied by the nurses. It has been found that patients experience relief from pain, improved pulse and respiration rate and a reduction in anxiety when they receive care in an interpersonal manner. ${ }^{8}$

Empathy is a teachable communicative skill. ${ }^{9}$ Empathic tendency and empathic skills should be taught in professional education as well as the professional implications that can be drawn from these. ${ }^{10}$ Many studies have reported that the empathic tendency and empathic skill scores of students are at medium levels. ${ }^{9,11-14}$ In studies conducted to understand the effectiveness of empathy training in nursing, it has been shown that empathy scores are statistically higher after the completion of training. ${ }^{15}$ Therefore, it is important to determine the empathic tendency and empathic and communication skills of undergraduate students and to accordingly improve the effectiveness of the courses teaching these skills. ${ }^{10}$ The courses focusing on the development of empathic skills, which include psychodrama and role taking and role model techniques, should be included as part of the academic curriculum in all health personnel training institutes. ${ }^{15}$ It is important to educate healthcare students on the importance of empathy as an inseparable part of their profession, to determine the empathic tendency of students and to improve their empathic skills. ${ }^{12}$ This study was conducted to determine the empathic tendency and empathic skill levels of nursing students.

\section{Methods}

\section{Setting, Study Design and Ethical Concerns}

This study was designed as a descriptive and cross-sectional study. The research was conducted in the Department of Nursing of a health college between March 3 - April 1, 2017.

\section{Study Population}

The study population consisted of 580 nursing students studying at a health college in the 2016-2017 academic years. As this study involved no sampling, attempts were made to reach the entire universe of prospective study participants. The study was based on voluntary participation. Students who did not agree to participate in the study (114 students) and who failed to completely fill out the survey forms (54 students) were excluded from the study. Data analysis was therefore carried out on 412 students. For data collection, the Personal Information form, Empathic Tendency Scale, and Empathic Skill Scale-B were used and personal interviews were conducted.

The Personal Information form consisted of 16 sociodemographic and work-related questions on a number of variables, such as gender, age, class, high school graduated from, the place where they lived the longest, income level, mother's and father's education level, family member who works in the healthcare field, whether they like their jobs, the area they are interested in working after graduation, the importance of empathy in nursing and the effect of their education on their motivation.

\section{Empathic Tendency Scale}

Developed by Dökmen (1988) to measure an individual's potential to develop empathy in their daily lives. It is composed of 20 statements, with responses arranged on a 5-point Likerttype scale. Approximately half of the scale contains negative sentences to counterbalance the tendency of the participants to mark 'yes'. The respondents express to what degree they agree with the view as referred to in the respective item by choosing the statements that correspond to values from 1 to 5. The items of the scale are stated in an inverse manner. The numbers marked function as the scores for the items, with negative statements being scored higher ( $1=$ agree to $5=$ disagree $)$. The total score expresses the empathic tendency scores of the respondent. Higher scores indicate higher empathic tendency levels, while lower scores indicate lower empathic tendency. The Cronbach's alpha reliability coefficient for the scale is $\mathrm{r}=0.82$. In our study, it was found to be 0.88 .

\section{Empathic Skill Scale}

The Empathic Skill Scale-B form developed by Dökmen (1988) is based on six different problems encountered in daily life. Each problem is followed by 12 empathic responses that can be addressed to a person suffering from the stated problem. Therefore, the respondent is provided with a total of 72 empathic responses (12 for each problem) in written form. Respondents are asked to indicate the statement with the highest level of importance, and the one with the second highest level of importance, the third highest level of importance and the fourth highest level of importance. One of the 12 responses is irrelevant to the problem but was intentionally included to identify those who are not paying attention. There are six irrelevant responses in the scale. Respondents are asked to select four of the responses that follow each problem. After they have chosen a total of 24 responses, their performance is graded. Higher scores indicate a higher empathy level, while lower scores indicate a lower empathy level. The Cronbach's alpha reliability coefficient for the scale is 0.83 . In our study, it was found to be 0.75 in our study

\section{Statistical Analysis}

The data collected was evaluated using SPSS software. Numbers, percentages and averages were used in the basic descriptive analysis of data. The Kolmogorov-Smirnov test was implemented to determine whether sample data was normally distributed. As the data had normal distribution and homogeneity of variances, the statistical analysis was conducted by parametric tests. The independent t-test was used to compare the mean scores of the two independent groups, while one-way analysis of variance (ANOVA) was used to 
compare the means of three or more variables. Tukey's test was used to determine any significant differences between the groups based on the findings from the variance analysis. Research results were evaluated with a $95 \%$ confidence interval and $p<0.05$ significance level.

\section{Results}

The students' mean score on the Empathy Skill Scale was $139.67 \pm 20.11$ and $68.84 \pm 8.42$ on the Empathy Tendency Scale (Table 1).

Table 1. Mean Scores of Emphatic Skill Scale (ESS) and Emphatic Tendency Scale (ETS)

\begin{tabular}{l|cc}
\hline Scales & Min-Max & $\mathbf{X} \pm$ ss \\
\hline Emphatic Skill Scale (ESS) & $41-93$ & $139.67 \pm 20.11$ \\
Emphatic Tendency Scale (ETS) & $90-207$ & $68.84 \pm 8.42$ \\
\hline
\end{tabular}

Regarding the socio-demographic data, $87.6 \%$ of the students were female, $64.8 \%$ were between 20 and 22 years of age (the mean age was $21.3 \pm 1.4$ ), and $27.2 \%$ were fourth-year students. To continue, $48.5 \%$ of the students resided the longest period of their lives in the province, and $63.3 \%$ of the students' mothers and $58.5 \%$ of the students' fathers were primary school graduates (Table 2).

Table 2 presents a comparison of the students' mean scores on empathic skills and empathic tendencies according to their demographic features. The findings show that the mean scores for the ETS and ESS were higher and had a statistically significant difference for women compared to men, the age group of 23 and 25 compared to the age groups of 17-19 and 20-22, fourth-year students compared to other year levels, students who lived in a city centers compared to those who lived in towns or rural areas, and students whose fathers graduated from university compared to those whose fathers graduated from high school/primary school/are literate $(p<0.05)$. Furthermore, the mean scores on the ETS and ESS were found to be higher for the students whose mothers graduated from university than for the students whose mothers graduated from high school/primary school/are literate, but no significant difference was found for mothers' education level and the mean ETS scores $(p<0.05)$.

Table 2. Comparing the mean scores of emphatic skill and emphatic tendency according to students' characteristics $(n=412)$

\begin{tabular}{|c|c|c|c|c|c|c|}
\hline Variables & $\mathbf{n}$ & $\%$ & $\begin{array}{c}\text { ESS } \\
\mathrm{X} \pm \text { Ss } \\
\end{array}$ & $\begin{array}{l}\text { ETS } \\
\text { X } \pm \text { sS }\end{array}$ & $\begin{array}{c}\mathbf{t} / \mathbf{F} \\
\text { EBÖ/ EEÖ }\end{array}$ & EBÖ $/{ }^{p}$ EEÖ \\
\hline \multicolumn{7}{|l|}{ Gender } \\
\hline Female & 361 & 87.6 & $141.16 \pm 20.26$ & $69.43 \pm 8.27$ & \multirow[b]{2}{*}{$\mathrm{t}=4.073 / 3.814$} & \multirow[b]{2}{*}{$0.000 * * * / 0.000 * * *$} \\
\hline Male & 51 & 12.4 & $129.13 \pm 15.51$ & $64.70 \pm 8.41$ & & \\
\hline \multicolumn{7}{|l|}{ Age } \\
\hline $17-19$ & 115 & 27.9 & $138.14 \pm 15.90$ & $68.62 \pm 8.02$ & \multirow{3}{*}{$\mathrm{F}=11.877 / 3.738$} & \multirow{3}{*}{$0.000 * * * / 0.025 *$} \\
\hline $20-22$ & 267 & 64.8 & $138.44 \pm 18.73$ & $68.49 \pm 8.19$ & & \\
\hline $23-25$ & 30 & 7.3 & $156.46 \pm 34.73$ & $72.86 \pm 10.9$ & & \\
\hline \multicolumn{7}{|l|}{ Class } \\
\hline First year & 95 & 23.1 & $137.46 \pm 15.26$ & $69.35 \pm 8.10$ & \multirow{4}{*}{$F=5.984 / 7.642$} & \multirow{4}{*}{$0.001 * * / 0.000 * * *$} \\
\hline Second year & 99 & 24.0 & $137.75 \pm 20.12$ & $66.31 \pm 8.39$ & & \\
\hline Third year & 106 & 25.7 & $136.37 \pm 20.89$ & $67.66 \pm 8.64$ & & \\
\hline Fourth year & 112 & 27.2 & $146.37 \pm 21.61$ & $70.08 \pm 7.57$ & & \\
\hline \multicolumn{7}{|l|}{ The place where he/she has lived the } \\
\hline longest & 200 & 48.5 & $143.08 \pm 21.54$ & $70.27 \pm 8.46$ & \multirow{4}{*}{$\mathrm{F}=8.742 / 8.327$} & \multirow{4}{*}{$0.000 * * * / 0.000 * * *$} \\
\hline City & 141 & 34.2 & $138.80 \pm 19.08$ & $68.41 \pm 7.25$ & & \\
\hline Town & 71 & 17.2 & $131.82 \pm 15.15$ & $65.69 \pm 7.25$ & & \\
\hline Village & & & & & & \\
\hline \multicolumn{7}{|l|}{ Mother's educational level } \\
\hline Literate (not attended any school) & 56 & 13.6 & $137.34 \pm 16.94$ & $65.19 \pm 6.77$ & \multirow{4}{*}{$F=0.857 / 4.646$} & \multirow{4}{*}{$0.463 / 0.000 * * *$} \\
\hline Primary school & 261 & 63.3 & $139.37 \pm 21.42$ & $69.10 \pm 8.13$ & & \\
\hline High school & 80 & 19.4 & $141.68 \pm 19.31$ & $70.32 \pm 9.08$ & & \\
\hline Bachelor's degree & 15 & 3.6 & $144.47 \pm 16.44$ & $70.33 \pm 11.83$ & & \\
\hline \multicolumn{7}{|l|}{ Father's educational level } \\
\hline Literate (not attended any school) & 23 & 5.6 & $137.22 \pm 22.50$ & $65.00 \pm 7.65$ & \multirow{4}{*}{$\mathrm{F}=2.962 / 4.844$} & \multirow{4}{*}{$0.032 * / 0.003 * *$} \\
\hline Primary school & 241 & 58.5 & $137.75 \pm 17.25$ & $68.07 \pm 7.75$ & & \\
\hline High school & 110 & 26.7 & $141.95 \pm 21.74$ & $70.74 \pm 8.61$ & & \\
\hline Bachelor's degree & 38 & 9.2 & $142.98 \pm 20.11$ & $71.63 \pm 10.82$ & & \\
\hline
\end{tabular}

$* p<0.05, * * p<0.01, * * * p<0.001$

A large majority $(90.3 \%)$ of the students agreed that empathy was important in nursing, $49.5 \%$ wanted to work as a clinic nurse after graduating, $63.6 \%$ stated that they voluntarily chose this profession, and $49.3 \%$ felt that their current education had an impact on their motivation (Table 3 ).

Table 3 presents a comparison of the mean scores for the empathic skills and empathic tendencies of the students according to their views on the profession of nursing. The mean scores on the empathic tendency and empathic skill levels of the students were higher for students who thought of empathy as being important in nursing, students who wanted to be an academic member after graduation, students who willingly chose the nursing profession, and students who loved their profession on account of the nursing education they had received, and a significant relationship was determined between all these variables and the empathic tendency levels $(p<0.05)$. 
Table 3. Comparing the average scores of emphatic skill and emphatic tendency according to students' perceptions on nursing profession ( $\mathrm{n}=412)$.

\begin{tabular}{|c|c|c|c|c|c|c|}
\hline Variables & $\mathbf{n}$ & $\%$ & $\begin{array}{c}\text { ESS } \\
\mathbf{X} \pm \text { sS }\end{array}$ & $\begin{array}{l}\text { ETS } \\
\mathbf{X} \pm \text { ss }\end{array}$ & $\begin{array}{c}\mathbf{t} / \mathbf{F} \\
\text { ESS-/ ETS }\end{array}$ & $\begin{array}{c}p \\
\text { ESS-/ ETS } \\
\end{array}$ \\
\hline \multicolumn{7}{|c|}{ Importance of empathy in nursing } \\
\hline Important & 372 & 90.3 & $139.98 \pm 20.42$ & $69.03 \pm 8.32$ & & \\
\hline Not important & 40 & 9.7 & $136.98 \pm 17.05$ & $58.28 \pm 8.17$ & $\mathrm{t}=0.355 / 3.389$ & $0.723 / 0.001 * *$ \\
\hline \multicolumn{7}{|c|}{ Profession desired to serve after graduation } \\
\hline Clinic nurse & 204 & 49.5 & $137.26 \pm 16.36$ & $68.37 \pm 7.58$ & & \\
\hline Academician & 121 & 29.4 & $143.35 \pm 23.86$ & $71.04 \pm 9.46$ & & \\
\hline Administrative nurse & 35 & 8.5 & $142.91 \pm 25.58$ & $67.28 \pm 8.64$ & $F=2.626 / 4.687$ & $0.054 / 0.003 * *$ \\
\hline Out of the professional field & 52 & 12.6 & $138.44 \pm 18.83$ & $66.63 \pm 7.96$ & & \\
\hline \multicolumn{7}{|l|}{ Choosing to be nurse } \\
\hline Willingly chosen & 262 & 63.6 & $148.35 \pm 18.43$ & $69.59 \pm 8.06$ & & \\
\hline Unwillingly chosen & 36 & 8.7 & $138.19 \pm 20.88$ & $65.27 \pm 8.83$ & $F=2.425 / 4.638$ & $0.090 / 0.010 *$ \\
\hline Undecided & 114 & 27.7 & $143.19 \pm 23.11$ & $68.25 \pm 8.82$ & & \\
\hline \multicolumn{7}{|c|}{$\begin{array}{l}\text { Impact of current education on loving } \\
\text { his/her profession }\end{array}$} \\
\hline Impacted positively & 203 & 49.3 & $148.17 \pm 18.29$ & $70.77 \pm 8.30$ & & \\
\hline Impacted negatively & 69 & 16.7 & $143.99 \pm 27.00$ & $67.05 \pm 7.92$ & $\mathrm{~F}=2.167 / 11.02$ & $0.116 / 0.000 * * *$ \\
\hline Unchanged & 140 & 34.0 & $139.74 \pm 18.44$ & $66.81 \pm 8.59$ & & \\
\hline
\end{tabular}

$* p<0.05, * * p<0.01, * * * p<0.001$

\section{Discussion}

Empathy involves the ability to facilitate communication in daily life. The development of positive interpersonal relationships has a direct effect on the nursing profession ${ }^{16,17}$. Therefore, it is important that nursing students learn empathic sensitivity and gain empathic skills during the course of their nursing education. This study, which was conducted to determine the empathic tendency and empathic skill levels of nurse candidates, found that the students' mean score on empathy skills was $139.67 \pm 20.11$. The mean score on empathy skills in other studies conducted on the same subject and involving nursing students were reported to be 129.4 by Uncu et al. ${ }^{14}, 124.7$ by Acaroğlu and Duman ${ }^{17}, 137.6$ by Özyazıcıŏlu et al. ${ }^{18}, 124.1$ by Yiğitbaş et al. ${ }^{12}$, and 163.6 by Karaca et al. ${ }^{10}$ In a study by Cevahir et al. ${ }^{19}$ involving midwifery students, the mean score on empathy skills was reported as 135.35. Our findings show similarities to those presented in the literature. The mean score on the empathic skills was reported to be higher in the study by Karaca et al., which can largely be attributed to the fact that the study involved first-year students in one school, without any control group. ${ }^{10}$ With the minimum possible score on the scale being 62 and the maximum, 219, the findings from our study as well as the others indicate that the empathic skills of the nursing students are generally at medium levels.

The nursing students' mean score on empathic tendency was determined to be $68.84 \pm 8.4$. The mean score on empathy tendency in other studies conducted on the same subject and involving nursing students were reported to be $69.9 \pm 9.3$ by Uncu et al. ${ }^{14}, 69.55$ by Tutuk et al. ${ }^{11}$, and 75.91 by Arifoğlu et al. ${ }^{20}$ In the case of final-year nursing students, the mean score on empathy tendency was found to be 66.07 by Yiğitbaş et al. ${ }^{12}$, and 68.45 by Karaca et al. ${ }^{10}$, while for midwifery students, the mean score was reported to be 69.59 by Bekmezci et al. ${ }^{13}$ These results show similarities to our findings. With the lowest score possible on the scale being 20 and the highest score, 100, the mean scores on the empathic tendency of the nursing students were above the medium level but did not reach higher levels. Montanari et al. ${ }^{21}$ and Carranza ${ }^{22}$, on the other hand found that the mean scores on empathic tendency of the nursing students in their study were high. In contrast to these two studies, the empathy levels of the nursing students in
Turkey were found to be at medium levels according to the literature. Richardson ${ }^{7}$ found that teaching student nurses about care, compassion and empathy significantly increases their empathy scores. This finding therefore suggests the importance of promoting the teaching of empathic tendency and empathic skills for student nurses in Turkey.

In comparing the mean scores on empathic tendency and empathic skill according to gender, it was found that the mean scores of females were higher than those of the males, with a statistically significant difference being found between them. Çakmak and Demirbaş reported that the empathic tendency score averages of the female students were higher than those of the male students' $(70.85 \pm 8.30)$ and that there was a significant difference between their empathic tendencies. ${ }^{23}$ Previous research on empathic tendency and empathic skill in the areas of nursing and healthcare, including studies by Montanari et al. ${ }^{21}$, Uncu ${ }^{14}$, Yiğitbaş ${ }^{12}$, Carranza ${ }^{22}$, Fields et al. ${ }^{24}$, Nazik and Arslan ${ }^{25}$ and Şen et al. ${ }^{26}$, found similar results in their studies. Yiğitbaş et al. ${ }^{12}$ associated this with the assumption that women are intuitively more sensitive in their instincts, while Şen et al. ${ }^{26}$ stated that this may be associated with the assumption that women are more emotional than men. Çakmak and Demirbaş ${ }^{23}$ stated that girls and boys go through different socialization processes due to the community and culture they live in, and that since these socialization processes attribute different gender roles to girls and boys, girls are perceived as being more emotional and more sensitive towards empathy. Our results are in parallel with those found in the literature.

The statistical analysis of the nursing students according to age indicated that the 23-25 age group had the highest mean scores on empathic tendency and empathic skill. A significant relationship was found between the ages of the nursing students and their mean scores on empathic tendency and empathic skill. Some of the studies in the literature suggest that there is no significant relationship between age and mean scores on empathic tendency and empathic skill. ${ }^{16,20}$, While others suggest that as the age increases, empathic tendency also increases. ${ }^{25}$ The results from this study align with those reported in the latter cited, suggesting that there is an 
improvement in empathic tendency and empathic skill levels as the age increases.

The statistical analysis of the nursing students according to their year level indicated that the fourth-year students had the highest mean scores on empathic tendency and empathic skill, with there being a significant difference found among the different year levels $(p<0.01)$. Saeidi et al. ${ }^{27}$ found a significant difference between first- and final-year students in terms of their empathy scores, and final-year students were found to be much more empathetic. Nazik and Arslan ${ }^{25}$ and Mete and Gerçek $^{28}$ also found that fourth-year students had higher scores on the empathic skill scale than the students in other grades. In contrast, Cevahir et al. ${ }^{19}$ reported that first-year students had the highest mean scores on empathic skill. Uncu et al. ${ }^{14}$ found similar results for first-year students but determined that the second-year students had the highest average. While our study found that although the first-year students did not have the lowest mean scores on empathic tendency and empathic skill, these scores can nonetheless be improved by developing a curriculum that offers more support in this area.

The empathic tendency and empathic skill levels of the nursing students were analyzed according to their longest place of residence. The nursing students whose longest places of residence were city centers had high scores on empathic tendency and empathic skill levels, while the students who lived in villages or towns had lower values, with there being a statistical difference among the places where the students resided $(p<0.001)$. This finding is similar with the findings of the study by Bekmezci et al. ${ }^{13}$ study on midwifery students. However Nazik and Arslan ${ }^{25}$ did not find any significant difference between the longest place of residence and scores on the empathic skill scale. The results from our study suggest that the empathic skills of the students who had at one time or another lived in towns or villages improve after they arrive to city centers. This could be due to the limitations of the social development opportunities in the living spaces.

This study also evaluated the empathic tendency and empathic skill levels of the nursing students according to their parents' education levels. It was found that the students whose parents were university graduates had higher mean scores on empathic tendency and empathic skill, with there being a significant relationship between the parents' education levels and the mean scores on empathic tendency and empathic skill $(p<0.05)$. Bekmezci et al. ${ }^{13}$ conducted a study on midwifery students and found there to be no statistical difference between the education levels of the parents and scores on empathic tendency and empathic skill. Uncu et al. ${ }^{14}$, however, found that the students whose mothers were university graduates had higher mean scores on the empathy skill scale compared to those of other students. Arifoğlu et al. ${ }^{20}$ conducted a study on nursing students where they did not find there to be a significant relationship between the parents' education level and the students' scores on empathic tendency and empathic skill. The results from our study indicate that as the parents' education levels increase, the empathic skills of the students also increase, which may suggest that highly educated parents contribute to the development of empathy skills in their children.

The study examined the empathic tendency and empathic skill levels of students according to their views of the nursing profession. The mean scores on the empathic levels of the students who believed that empathy was important in nursing, who wanted to be an academic member after graduation, who willingly chose the nursing profession, and who loved their profession as a result of the nursing education they had thus far received were higher than those of the others, with there being a significant relationship found between the empathic levels and all of these variables $(p<0.01)$. This result indicates that nursing students who understand the importance of empathy in their professions, who are open to professional development, and who willingly choose their profession have greater empathic tendencies. Çınarlı et al. ${ }^{29}$ also found that students who willingly chose their profession had higher scores on the empathic tendency scale.

The research results indicate the following:

-The total scores on the empathic tendency and empathic skill scale of the nursing students participating in the research are at a medium level,

-The students' gender, age, class, longest place of residence, and their parents' education level affect the empathic tendencies and the empathic skills of them,

-A medium level positive relationship exists between the empathic tendencies and the empathic skills of the nurses.

From these results, it can be recommended that empathic tendency and empathic skills be taught as part of the education process and that the courses directed towards this type of instruction be included in the academic curriculum to promote greater empathy in the students.

\section{Compliance of Ethical Statement}

Ethical permission was acquired for the research by the Clinical Research Ethical Board (Decision number: 2017/16 on March 1, 2017). This study was conducted based on the voluntary participation of the students.

\section{Conflict of Interest}

There are no conflicts of interest.

\section{Acknowledgments \\ None declared}

\section{Financial Disclouse/Statement}

None declared

\section{Author Contribution}

All authors contributed equally to the preparation of the article

\section{References}

1. Han JH, Yang JY, Hwang JM. Effects of empathic ability and campus life stress on stress coping behaviors in dental hygiene students. $J$ Dent Hyg Sci. 2017;17(5):439-446. doi:10.17135/jdhs.2017.17.5.439

2. Jang, H.S. The effects of self-disclosure and empathy on stress perception and stress coping strategy of university students. Korean Journal of Communication Studies. 2013;21(3):5-28.

3. Barret-Lennard G. The empathy cycle: Refinement of a nuclear concept. Journal of Consulting Psychology.1981;28:91-100. doi:10.1037/0022-0167.28.2.91

4. Dökmen Ü. Communication Conflicts and Empathy. Sistem Publishing, İstanbul, 1994; p.119-150.

5. Rehber E, Atic1 M. Determination of conflict resolution behaviors according to empathic tendency level of secondary school students. Journal of Çukurova University Institute of Social Sciences. 2009;18(1):323-342.

6. Uslu N, Bayat M, Variyenli N, Arıcan F, Hatipoğlu N. Orlando'nun etkileşim teorisinin uygulamada kullanımına bir örnek: Tip 1 diyabetes mellitus.Ylldırım Beyazıt University Faculty of Health Sciences E-Journal of Nursing. 2015;3(1):6470.

7. Ferri P, Rovesti S, Panzera N, Marcheselli L, Bari A, Lorenzo RD. Empathic attitudes among nursing students: a preliminary study. Acta Biomed for Health Professions. 2017;88(3):22-30. doi:10.23750/abm.v88i3-S.6610. 
8. Reynolds W, Scott B. Do Nurses And Other Professional Helpers Normally Display Much Empathy. Journal of Advanced Nursing. 2000;31:226-234. doi:10.1046/j.13652648.2000.01242.x

9. Öz F. The relations between empathic tendency, empathic skills and academic performance of senior students of nursing. Journal of Cumhuriyet University School of Nursing. 1998;2(2):10-16.

10. Karaca A, Açıkgöz F, Akkuş D. Can empathic skills and empathic tendencies be improved by education? Example of a health school. Acrbadem University Journal of Health Sciences. 2013;4(3):118-122.

11. Tutuk A, Al D, Doğan S. Determination of communication skills and empathy levels of nursing students. Journal of Cumhuriyet University School of Nursing. 2002;6(2):36-41.

12. Yiğitbaş Ç, Deveci SE, Yasemin A, Ozan AT, Oğuzöncül AF. The empathic tendency and empathic skills of a group of students receiving health education. SDU Journal of Health Science. 2013;4(1):7-13.

13. Bekmezci H, Yurttaş Ç, Özkan H. Ebelik Bölümü Öğrencilerinin Empatik Eğilim Düzeylerinin Belirlenmesi. HSP. 2014;2(1):4654.

14. Uncu F, Açık Y, Deveci S, Çelebi E, Oğuzöncül A, Ulaş B. Determination of empathic tendency and empathic skill levels of nursing students studying at health school. Yıldirım Beyazıt University Faculty of Health Sciences E-Journal of Nursing. 2015;3(3):1-8.

15. Richardson C, Percy M, Hughes J. Nursing therapeutics: Teaching student nurses care, compassion and empathy. Nurse Educ Today. 2015;35(5):1-5. doi:10.1016/j.nedt.2015.01.016

16. Özcan H. Empathic disposition and empathic skills of nurses: Example Gümüşhane. Gümüşhane University Journal of Health Science. 2012;1(2):60-68.

17. Acaroğlu R, Duman D. The relationship between emotional intelligence levels and empathy skills of nursing college's first grade students. Florence Nightingale Journal of Nursing. 2014;22(1):25-32.

18. Özyazıcıoğlu N, Aydınoğlu N, Aytekin G. The investigation of the problem solving and empathetic skills of the students in a school of health. Journal of Anatolia Nursing and Health Sciences. 2009;12(3):46-53.
19. Cevahir R, Cınar N, Sözeri C, Sahin S, Kuğuoğlu S. Evaluation of the empathic skills of midwifery students with respect to the classes they are attending. Firat Health Services Journal. 2008;3(7):3-15.

20. Arifoğlu B, Sala Razı G. Management course academic achievement averages of first class nursing students. DEUHYO ED. 2011;4(1):7-11.

21. Montanari P, Petrucci C, Russo S, Murray I, Dimonte V, Lancia L. Psychometric properties of the Jefferson Scale of Empathy Health Professional Student's version: An Italian validation study with nursing students. Nursing \& Health Sciences. 2015;17(4):483-491. doi:10.1111/nhs.12221

22. Carranza AN. Clinical Simulation Experiences in Nursing Schools: Senior Student Nurses' Empathetic Communication Ability. [Honors Thesis], Texas; 2015.

23. Çakmak A, Demirbaş EA. Review of the emphatic tendencies of university students in terms of some variables. International Journal of Humanities and Social Science. 2014;7(1):29-33.

24. Fields SK, Mahan P, Tillman P, Harris J, Maxwell K, Hojat M. Measuring empathy in healthcare profession students using the Jefferson Scale of Physician Empathy: health provider--student version. $J$ Interprof Care. 2011;25(4):287-293. doi:10.3109/13561820.2011.566648

25. Nazik E, Arslan S. The investigation of the relations between empathic skills and self-compassion of the nursing students. Journal of Anatolia Nursing and Health Sciences. 2011;14(4):69-75.

26. Şen HT, Yılmaz FT, Ünüvar ÖP, Demirkaya F. Emphatic skill levels of primary health care workers. Journal of Psychiatric Nursing. 2012;3(1):6-12.

27. Saeidi S, Reza-Masouleh S, Chehrzad MM, Kazem Nejad Leili E. Empathy with patients compared between first and final year nursing students. Journal of Holistic Nursing And Midwifery. 2017;27(1):79-85. doi:10.18869/acadpub.hnmj.27.1.79

28. Mete S, Gerçek E. The Examınatıon of empathic tendency and skills on nursing students who are educated with $\mathrm{Pbl}$ method. Journal of Cumhuriyet University School of Nursing. 2005;9(2):11-7.

29. Çınarlı T, Koç Z, Duran L. Burnout and empathic tendency levels in emergency nurses. Eurasian $J$ Emerg Med. 2016;15:181-186. doi:10.5152/eajem.2016.43434. 